\title{
PARTISIPASI MASYARAKAT DALAM PEMBANGUNAN FISIK DESA (Studi di Desa Banga Kecamatan Mawasangka Kabupaten Buton Tengah)
}

\author{
Asri Yanti ${ }^{1}$, Arsidik Asuru ${ }^{2}$, Andi Syahrir P $^{3}$ \\ Jurusan Pendidikan Pancasila dan Kewarganegaraan \\ Fakultas Keguruan dan Ilmu Pendidikan \\ Universitas Halu Oleo \\ Email: asriyanti@gmail.com ${ }^{1}$, Arsidikasuru@gmail.com ${ }^{2}$, \\ Andisyahrir@gmail.com ${ }^{3}$
}

\begin{abstract}
Abstrak: Tujuan penelitian ini adalah untuk mengetahui: (1) bentuk partisipasi masyarakat dalam pembangunan fisik di desa Banga Kecamatan Mawasangka; dan (2) faktor-faktor yang mempengaruhi partisipasi masyarakat dalam pembangunan fisik di desa Banga Kecamatan Mawasangka. Hasil penelitian menunjukkan bahwa: 1. bentuk partisipasi masyarakat dalam pembangunan fisik desa diklasifikasikan dalam tiga bentuk, yakni: (a) Keikutsertaan dalam musyawarah dan memberikan usulan/saran perihal program pembangunan yang akan dijalankan untuk disetujui bersama. Secara konkret berwujud: kehadiran masyarakat dalam setiap pertemuan, memberikan beberapa usulan/masuka-masuk dalam pertemuan, hingga terlibat dalam pertemuan nonformal yang membahas program pembangunan yang akan dilaksanakan; (b) Keikutsertaan dalam pelaksanaan/realisasi program pembangunan. secara konkret berwujud sumbangan berupa tenaga, pikiran, dana, alat-alat/bahan-bahan kerja; dan (c) Keikutsertaan mengawasi, mengevaluasi dan memelihara hasil pelaksanaan pembangunan. Pengawasan dan evaluasi secara sederhana berfungsi untuk mengetahui sejauh mana suatu pembangunan berjalan sesuai dengan ketentuan yang telah ditetapkan. 2. terdapat empat faktor yang mempengaruhi partisipasi masyarakat dalam pembangunan fisik desa yakni: (a) pengetahuan dan keterampilan; (b) tingkat pendidikan dimana terdapat partisipasi dominan yang diklasifikasi pada dua tingkatan pendidikan yakni maksimal tamat SMP dan Minimal tamat SMA; (c) Pekerjaan dan penghasilan Pekerjaan dan penghasilan memberikan pengaruh besar pada partisipasi dalam bentuk perencanaan/ penggagasan dan realisasi program pembangunan (d) Kebudayaan memberikan pengaruh yang cukup besar dan positif untuk pembangunan desa yakni melalui adanya budaya gotong royong yang menjadikan percepatan pembangunan. Kesimpulan adalah (1) bentuk partisipasi masyarakat dalam pembagunan fisik desa sudah terlaksa dengan baik, (2) faktor-faktor yang mempengaruhi partisipasi masyarakat dalam pembangunan desa (a) faktor internal (b) faktor eksternal.
\end{abstract}

\section{Kata Kunci: Partisipasi Masyarakat, Pembangunan Fisik.}

\section{PENDAHULUAN}

Partisipasi masyarakat dalam pembangunan merupakan salah satu wujud kepedulian masyarakat terhadap pelaksanaan pembangunan. Partisipasi masyarakat juga merupakan salah satu faktor yang berpengaruh terhadap berhasil tidaknya program pembangunan dalam suatu wilayah. Partisipasi masyarakat di perlukan karena program pemerintah yang dilaksanakan tidak lain adalah untuk masyarakat. Maka sudah semestinya jika masyarakat dan pemerintah berpartisipasi langsung dalam berbagai bentuknya guna meningkatkan serta mempermudah jalannya pelaksanaan program pembangunan desa.

Pembangunan pedesaan masih merupakan hal yang sangat penting dilakukan melihat dari kenyataan yang ada bahwa persoalan dasar pembangunan 
pada hakekatnya berada di pedesaan. Masyarakat lokal dengan pengetahuan serta pengalamannya menjadi modal yang sangat besar dalam melaksanakan pembangunan, karena masyarakat lokal yang mengetahui apa permasalahan yang dihadapi serta potensi yang dimiliki oleh desanya. Masyarakat desa setempat memiliki kedaulatan yang cukup luas untuk menentukan orientasi dan arah kebijakan pembangunan yang dikehendaki. Sastropoetra (2005: 75) kemudian mendefinisikan partisipasi sebagai keterlibatan mental atau pikiran dan emosi atau perasaan seseorang dalam situasi kelompok yang mendorongnya untuk memberikan sumbangan kepada laporan kelompok dalam uasaha mencapai tujuan serta turut bertanggung jawab terhadap usaha yang bersangkutan.

Pembangunan di desa pada dasarnya adalah pembangunan masyarakat di lingkungannya, yaitu pembangunan masyarakat seutuhnya. Perlu disadari bahwa pembangunan desa merupakan tanggung jawab bersama-sama antara pemerintah dan masyarakat. Agar pembangunan desa dapat berjalan dengan lancar maka perlu adanya penyesuaian program antara pemerintah dengan masyarakat. Wadah kerjasama dalam pembangunan desa adalah Badan Perwakilan Desa (BPD), yang terdiri atas wakil-wakil masyarakat yang ada di Desa.

Keterlibatan atau keikutsertaan seluruh lapisan masyarakat dalam memberikan partisipasi pada setiap program pembangunan dapat berupa sumbangan pemikiran atau pemberian ide-ide keterlibatan secara fisik atau tenaga, serta ikut merasakan hasil-hasil pogram pembangunan itu sendiri. Sejalan dengan hal tersebut lebih lanjut Tjokroamidjojo (2004: 207) mengemukakan bahwa partisipasi masyarakat adalah keterlibatan aktif masyarakat dalam proses penentuan arah, strategi dan kebijaksanaan pembangunan yang dilakukan pemerintah, keterlibatan dalam memikul beban dan tanggung jawab pembangunan secara berkeadilan.

Dengan kata lain, partisipasi masyarakat Desa Banga Kecamatan Mawasangka Kabupaten Buton Tengah sangat dibutuhkan untuk keberhasilan pembangunan di desa tersebut untuk terwujudnya pembangunan Desa yang dapat mendukung terwujudnya pembangunan nasional. Selain itu, peran dan kinerja pemerintah Desa juga sangat diharapkan untuk dapat menjalankan tugas pokok pemimpin dan mengkoordinasikan dalam melaksanakan urusan rumah tangga Desa, melakukan pembinaan, pembangunan masyarakat dan membina perekonomian desa. Secara khusus dapat memberdayakan masyarakat di desa Banga Kecamatan Mawasangka Kabupaten Buton Tengah untuk berpartisipasi dalam mencapai kemajuan dan pengembangan desa merupakan sasaran utama dari pemerintah Desa.

Dengan demikian dapat dikatakan bahwa untuk dapat terwujudnya pembangunan desa yang berkelanjutan diperlukan peran serta dari berbagai pihak. Dua unsur penting yang seharusnya terlibat dalam pembangunan tersebut adalah pemerintah desa dan masyarakat Desa setempat. Dalam hal ini, pemerintah desa bersama masyarakat dapat melakukan pembangunan desa secara bersama-sama mulai dari tahap perencanaan hingga tahap evaluasi dan pemeliharaan. Oleh karena itu, pembangunan tidak akan dapat berjalan dengan baik jika salah satu pihak tidak berpartisipasi aktif dalam pembangunan Desa.

Masalah yang terkait dengan partisipasi masyarakat dalam pembangunan Desa pada umumnya adalah melemahnya keinginan/ kemauan masyarakat untuk terlibat dalam pembangunan ats dasar pemikiran bahwa pembangunan tidak 
penting atau tidak sesuai dengan kebutuhan masyarakat, atau karena tidak diberikannya kesempatan oleh pemerintah desa untuk masyarakat desa terlibat langsung. Dalam konsep pembangunan, partisipasi masyarakat menjadi salah satu aspek yang sangat penting. Pembangunan berbasis partisipasi masyarakat tentu saja diarahkan pada perbaikan kondisi hidup masyarakat itu sendiri. Pembangunan di suatu wilayah oleh masyarakat menjadi salah satu upaya untuk mengubah keadaan dari yang kurang bermanfaat menuju keadaan yang lebih baik. Oleh karena itu partisipasi masyarakat merupakan salah satu aspek penting yang dapat menentukan berhasil tidaknya suatu pembangunan.

Konsep Partisipasi berasal dari bahasa inggris yaitu dari kata "participation" yang dapat diartikan sebagai kegiatan untuk membangkitkan perasaan dan diikut sertakan atau ambil bagian dalam kegiatan suatu organisasi (Slamet, 1994: 45). Partisipasi berarti peran serta seseorang atau kelompok masyarakat dalam proses pembangunan baik dalam bentuk pernyataan maupun dalam bentuk kegiatan dengan memberi masukan berupa pikiran, tenaga, waktu, keahlian, modal dan atau materi, serta ikut memanfaatkan dan menikmati hasilhasil pembangunan (Sumaryadi, 2010: 46).

Menurut Tilaar (2009: 287) partisipasi adalah sebagai wujud dari keinginan untuk mengembangkan demokrasi melalui proses desentralisasi dimana diupayakan antara lain perlunya perencanaan dari bawah (bottom-up) dengan mengikutsertakan masyarakat dalam proses perencanaan dan pembangunan masyarakatnya. Sementara itu, Adisasmita (2006: 34) mengatakan bahwa partisipasi anggota masyarakat adalah keterlibatan anggota masyarakat dalam pembangunan, meliputi kegiatan dalam perencanaan dan pelaksanaan (implementasi) program/proyek pembangunan yang dikerjakan di dalam masyarakat lokal. Hal senada juga dikemukakan oleh Chandra (2003: 5) yang menjelaskan bahwa partisipasi sebagai pengetahuan dan teknik yang ditujukan sebagai alat penyelesaian masalah-masalah pembangunan, berjalan dan tidaknya, tergantung pada konteks-konteks spesifik yang terkait dengan faktor-faktor struktural, norma-norma yang berlaku, organisasi sosial, pola-pola hubungan kekuatan, pola-pola tindakan bersama, serta institusi-institusi politik yang telah digunakan sebelumnya dalam komunitas.

\section{Konsep Masyarakat}

Masyarakat memiliki arti sekelompok orang yang membentuk sebuah sistem semi tertutup atau terbuka. Masyarakat terdiri atas individu-individu yang saling berinteraksi dan saling tergantung satu sama lain atau disebut zoon polticon. Dalam proses pergaulannya, masyarakat akan menghasilkan budaya yang selanjutnya akan dipakai sebagai sarana penyelenggaraan kehidupan bersama. Oleh sebab itu, konsep masyarakat dan konsep kebudayaan merupakan dua hal yang senantiasa berkaitan dan membentuk suatu sistem (Syani, 1995: 84). Dalam pendapat lainnya dijelaskan bahwa Masyarakat atau komunitas adalah menunjuk pada bagian masyarakat yang bertempat tinggal di suatu wilayah degan batasanbatasan tertentu, dimana yang menjadi dasarnya adalah interaksi yang lebih besar dari anggota-anggotanya, dibandingkan dengan penduduk di luar batas wilayahnya (Soekanto, 1999: 45).

\section{Konsep Pembangunan Fisik Desa}

Pembangunan adalah suatu proses kegiatan yang berlangsung dalam jangka waktu yang panjang dan terus menerus. Dengan kata lain, pembangunan ini 
bersifat dinamis. Kondisi dinamis dalam pembangunan tersebut bisa dilihat dalam dua konteks, yakni yang pertama adalah masyarakat itu yang selalu berubah, dan kedua bahwa pembangunan itu sendiri dimaksudkan untuk membawa perubahan yakni dari kondisi yang sekarang menuju kondisi lain di masa depan yang lebih baik dan bijaksana (Tjiptoherijanto, 1993: 15).

Menurut Kansil (2011: 253) pembangunan desa adalah pembangunan yang dilakukan di Desa secara menyeluruh dan tepadu dengan imbangan kewajiban yang serasi antara pemerintah dan masyarakat, dimana pemerintah memberikan bimbingan, pengarahan, bantuan dan fasilitas yang diperlukan dan masyarakat memberikan partisipasinya dalam bentuk swakarsa dan swadaya gotong royong pada setiap pembangunan yang diinginkan.

Keikutsertaan masyarakat dalam pembangunan merupakan salah satu cara yang efektif untuk menampung dan mengakomodasi berbagai kebutuhan yang beragan. Dengan kata lain, upaya peningkatan partisipasi masyarakat pada perencanaan pembangunan dapat membawa keuntungan substantif, dimana pelaksanaan pembangunan akan lebih efektif dan efisien, disamping itu juga akan memberi sebuah rasa kepuasan dan dukungan masyarakat yang kuat terhadap program-program pemerintah. Sehubungan dengan keterlibatan masyarakat dalam pembagunan, ditingkat desa terdapat lembaga yang salah satu fungsi menampung aspirasi masyarakat yaitu Badan Permusyarawatan Desa (BPD) sebagai mitra kerja pemerintah desa.

Berbagai sudut pandang dapat digunakan untuk menelaah pembangunan pedesaan sebagaimana diungkapkan oleh Haeruman (Kurniawan, 2016: 12-14) bahwa ada tiga sisi pandang untuk menelaah pembangunan pedesaan, yaitu:

a. Pembangunan pedesaan dipandang sebagai suatu proses alamiah yang bertumpu pada potensi yang dimiliki dan kemampuan masyarakat Desa itu sendiri. Pendekatan ini meminimalkan campur tangan dari luar sehingga perubahan yang diharapkan berlangsung dalam rentang waktu yang panjang;

b. Sisi yang lain, memandang bahwa pembangunan pedesaan sebagai suatu interaksi antar potensi yang dimiliki oleh masyarakt Desa dan dorongan dari luar untuk mempercepat pemabangunan pedesaan.

c. Pembangunan Desa adalah proses kegiatan pembangunan yang berlangsung di Desa yang mencakup seluruh aspek kehidupan dan penghidupan masyarakat.

Menurut Peraturan Pemerintah Republik Indonesia Nomor 43 Tahun 2014 tentang Desa disebutkan bahwa perencanaan pembangunan Desa disusun secara partisipatif oleh pemerintahan Desa sesuai dengan kewenangannya dan menurut ayat (3) bahwa dalam menyusun perencanaan pembangunan Desa wajib melibatkan lembaga kemasyarakatan Desa dengan tujuan sebagai berikut:

1) Mengkoordinasikan antar pelaku pembangunan;

2) Menjamin sinkronisasi dan sinergi dengan pelaksanaan pembangunan daerah;

3) Menjamin keterkaitan dan konsistensi antara perencanaan, penganggaran, pelaksanaan dan pengawasan;

4) Mengoptimalkan partisipasi masyarakat;

5) Menjamin tercapainya penggunaan sumber daya Desa secara efisien, efektif, berkeadilan dan berkelanjutan.

\section{Bentuk-bentuk Partisipasi Masyarakat dalam Pembangunan Fisik Desa}

Adapun bentuk-bentuk partisipasi yang diberikan masyarakat dalam tahap pembangunan Menurut Slamet (1994: 89) yaitu: 
1. Partisipasi dalam tahap perencanaan (ideal planning stage). Partisipasi dalam tahap ini maksudnya adalah pelibatan seseorang pada tahap penyusunan rencana dan strategi dalam penyusunan kepanitiaan dan anggaran pada suatu kegiatan/proyek. Masyarakat berpartisipasi dengan memberikan usulan, saran dan kritikan melalui pertemuan-pertemuan yang diadakan partisipasi.

2. Partisipasi dalam tahap pelaksanaan (implementation stage). Partisipasi dalam tahap ini maksudnya adalah pelibatan seseorang pada tahap pelaksanaan pekerjaan suatu kegiatan/proyek. Masyarakat dapat memberikan bantuan tenaga,uang, ataupun material/barang serta ide-ide sebagai salah satu wujud partisipasi pada pekerjaan tersebut.

3. Partisipasi dalam pemanfaatan (utilization stage). Partisipasi pada tahap ini maksudnya adalah pelibatan seseorang pada tahap pemanfaatan suatu pekerjaan/proyek, setelah proyek tersebut selesai dikerjakan. Partisipasi masyarakat pada tahap ini berupa tenaga dan uang untuk mengoprasikan dan memelihara proyek yang telah dibangun.

Bentuk-bentuk partisipasi menurut Ndraha (2002: 103), meliputi:

a. Peran serta dalam/melalui kontak dengan pihak lain (contact change) sebagai suatu titik awal dalam perubahan sosial;

b. Peran serta dalam memperhatikan atau menyerap dan memberikan tanggapan terhadap informasi, baik dalam arti menerima (menaati, memenuhi, dan melaksanakan) menerima dengan syarat maupun dalam arti menolaknya;

c. Peran serta dalam pelaksanaan operasional pembangunan;

d. Peran serta dalam menerima, memelihara, dan mengembangkan hasil pembangunan; dan

e. Peran serta dalam menilai pembangunan yaitu keterlibatan masyarakat dalam penilaian sejauh mana pelaksanaan pembangunan sesuai dengan rencana dan sejauh mana hasilnya dapat memenuhi kebutuhan masyarakat.

Sementara itu, bentuk-bentuk partisipasi masyarakat dalam pembangunan Desa menurut Septyasa (2013: 6) yaitu: (a) partisipasi buah pikiran; (b) partisipasi tenaga, yang diberikan partisipasi dalam berbagai kegiatan untuk perbaikan atau pembangunan desa, pertolongan bagi orang lain dan sebagainya; (c) partisipasi harta benda, yang diberikan orang dalam berbagai kegiatan untuk perbaikan atau pembangunan desa, pertolongan bagi orang lain yang biasanya berupa uang, makanan dan sebagainya; (d) partisipasi keterampilan dan kemahiran; dan (e) Partisipasi sosial, yang diberikan orang sebagai tanda keguyuban.

\section{Faktor-Faktor yang Mempengaruhi Partisipasi Masyarakat}

Keterlibatan masyarakat dalam suatu kegiatan kaitannya dengan partisipasi, menurut Dusseldorp (1981: 24-25) terdapat dua bentuk partisipasi berdasarkan derajat kesukarelaan, yakni:

1. Partisipasi bebas yakni terjadi bila seseorang individu melibatkan dirinya secara sukarela di dalam suatu kegiatan partisipasi tertentu. Partisipasi bebas dapat dibagi menjadi dua katagori yaitu: (a) partisipasi spontan terjadi bila seseorang individu mulai berpartisipasi berdasarkan pada keyakinan tanpa dipengaruhi melalui penyuluhan atau ajakan oleh lembaga-lembaga atau orang lain; dan (b) partisipasi terbujuk adalah jika seseorang individu mulai berpartisipasi setelah diyakinkan melalui penyuluhan atau oleh pengaruh lain sehingga berpartisipasi secara sukarela didalam aktivitas kelompok tertentu. 
2. Partisipasi terpaksa dapat terjadi dalam berbagai cara, yaitu partisipasi terpaksa oleh hukum dan terpaksa keadaan sosial ekonomi. Partisipasi terpaksa oleh hukum terjadi bila orang-orang dipaksa melalui peraturan atau hukum, berpartisipasi di dalam kegiatan-kegiatan tertentu tetapi bertentangan dengan keyakinan mereka dengan derajat pemaksaan yang berbeda-beda, sedangkan Partisipasi terpaksa karena kondisi ekonomi terjadi bila seseorang yang tidak turut di dalam suatu kegiatan akan mendapatkan kesulitan dalam aspek sosial ekonomi, misalnya bila seseorang tidak turut serta dalam pemeliharaan prasarana lingkungan dikampungnya maka ia akan disisihkan dari pergaulan tetangganya.

Kemudian Slamet (1994: 97-99) secara lebih rinci menjelaskan bahwa terdapat beberapa faktor baik faktor internal maupun faktor eksternal yang mempengaruhi partisipasi masyarakat dalam pembangunan yang dapat diuraikan sebagai berikut:

1. Faktor internal:

a. Jenis kelamin. Partisipasi yang diberikan oleh seorang pria dan wanita dalam pembangunan adalah berbeda. Hal ini disebabkan oleh adanya sistem pelapisan sosial yang terbentuk dalam masyarakat yang membedakan kedudukan dan derajat, hal ini akan menimbulkan perbedaanperbedaan hak dan kewajiban antara pria dan wanita;

b. Usia. Perbedaan usia akan mempengaruhi partisipasi masyarakat. Dalam masyarakat terhadap perbedaan kedudukan dan derajat atas dasar senioritas, sehingga akan memunculkan golongan tua dan golongan muda yang berbeda-beda dalam hal-hal tertentu seperti, menyalurkan pendapat dan megambil keputusan;

c. Tingkat pendidikan. Salah satu faktor yang mempengaruhi tingkat pengetahuan adalah tingkat pendidikan. Semakin tinggi latar belakang pendidikannya, tentu mempunyai pengetahuan yang luas tentang pembangunan dan bentuk serta tata cara partisipasi yang dapat diberikan. Faktor pendidikan dianggap penting, karena dengan pendidikan yang diperoleh, seseorang lebih mudah berkomunikasi dengan orang luar dan cepat tanggap terhadap inovasi;

d. Tingkat penghasilan. Dalam hal ini, penduduk yang lebih kaya kebanyakan membayar pengeluaran secara tunai dan jarang melakukan kerja fisik sendiri. Sementara penduduk yang berpenghasilan pas-passan cenderung berpartisipasi dalam hal tenaga;

e. Mata pencaharian. Hal ini berkaitan dengan tingkat penhasilan seseorang. Dengan demikian dapat dikatakan bahwa mata pencaharian dapat mempengaruhi partisipasi masyarakat dalam pembangunan. Hal ini disebabkan pekerjaan akan berpengaruh terhadap waktu luang seseorang untuk terlibat dalam pembangunan, misalnya dalam hal menghadiri pertemuan, kerjabakti dan lain-lain; dan

f. Lamanya tinggal. Lamanya seseorang tinggal dalam lingkungan tertentu dan pengalamannya berinteraksi dengan lingkungan tersebut akan berpengaruh pada partisipasi seseorang. Semakin lama ia tinggal dalam lingkungan tertentu, maka rasa memiliki terhadap lingkungan cenderung lebih terlihat dalam partisipasinya yang besar dalam setiap kegiatan lingkungan tersebut. 
2. Faktor eksternal:

a. Komunikasi yang intensif antara sesama warga warga masyarakat, antara warga masyarakat dengan pimpinannya serta antara sistem sosial di dalam masyarakat dengan sistem diluarnya;

b. Iklim sosial, ekonomi politik dan budaya, baik dalam kehidupan keluarga, pergaulan, permainan, sekolah maupun masyarakat dan bangsa yang menguntungkan serta mendorong tumbuh dan berkembangnya partisipasi masyarakat;

c. Kesempatan untuk berpartisipasi, keadaan lingkungan serta proses dan struktur sosia, sistem nilai dan norma-norma yang memungkinkan dan mendorong terjadinya partisipasi sosial; dan

d. Kebebasan untuk berprakarsa dan berkreasi. Lingkungan di dalam keluarga masyarakat atau lingkungan politik, sosial, budaya yang memungkinkan dan mendorong timbul dan berkembangnya prakarsa, gagasan, perseorangan atau kelompok.

\section{METODE PENELITIAN}

Penelitian ini bersifat deskriptif dengan pendekatan kualitatif yaitu peneliti memberikan gambaran (deskripsi) secara ilmiah dari data yang didapatkan di lapangan mengenai partisipasi masyarakat dan faktor-faktor yang mempengaruhinya dalam hal pembangunan fisik di Desa Banga Kecamatan Mawasangka Kabupaten Buton Tengah. Sumber data dalam penelitian ini yaitu: 1) Data Primer, berupa data yang diperoleh dari informan penelitian terbagi atas bentuk-bentuk partisipasi masyarakat dalam mendukung pembangunan fisik di desa dan faktor-faktor yang mempengaruhi pembangunan fisik di desa. merupakan sumber data yang secara langsung memberikan data kepada peneliti; dan 2) Data Sekunder, yakni data yang tidak lansung memberikan data kepada peneliti dalam bentuk dokumen, buku dan artikel. Informan penelitian yaitu: kepala desa, ketua/anggota BPD, tokoh masyarakat, tokoh pemuda dan ketua/anggota karang taruna Desa Banga Kecamatan Mawasangka Kabupaten Buton Tengah. Teknik dalam pengumpulan data yang digunakan adalah: 1) Penelitian kepustakaan; 2) Penelitian lapangan, terdiri dari: wawancara dan dokumentasi. Teknik analisis data menggunakan data kualitatif yakni Data Reduction (Reduksi Data); Data Display (Penyajian Data); dan Conclution Drawing/Verivication (Penarikan Kesimpulan). Miles dan Huberman (Sugiyono, 2014)

\section{HASIL PENELITIAN DAN PEMBAHASAN \\ Bentuk Partisipasi Masyarakat dalam Pembangunan Fisik di Desa Banga Kecamatan Mawasangka Kabupaten Buton Tengah}

Partisipasi masyarakat adalah keikut sertanya setiap individu atau kelompok masyarakat dalam suatu kegiatan desa untuk mencapai tujuan bersama disertai adanya pembagian kewenangan dan tanggungjawab bersama yakni antara masyarakat dengan pemerintah Desa. Partisipasi masyarakat dapat berada pada tiga tingkatan yakni: rendah, sedang dan tinggi dengan indikator yang berbedabeda. Semakin tinggi partisipasi masyarakat dalam pembangunan desa maka akan semakin baik dan kompleks pembangunan fisik desa yang akan dibangun. Sebaliknya, rendahnya partisipasi masyarakat dapat berdampak pada desa yang tidak akan memadai dalam pembangunan dan pemanfaatannya. 
Partisipasi masyarakat akan sangat mempengaruhi pembangunan desa. Dalam hal ini, konsep otonomi daerah yang memberikan wewenang pada daerah untuk mengurus urusan rumah tangganya sendiri menjadi tidak berguna. Dalam konsep otonomi daerah tersebut sangat menekankan pada peran serta masyarakat setempat untuk menggerakkan dan menjalankan pembangunan suatu daerah. Sejauh mana tingkat partisipasi masyarakat desa Banga dapat dilihat dari bentuk keterlibatannya dalam setiap kegiatan Desa. Berdasarkan hasil penelitian, diketahui terdapat tiga bentuk partispasi masyarakat dalam pembangunan fisik di Desa Banga Kecamatan Mawasangka Kabupaten Buton Tengah diantaranya dapat diuraikan sebagai berikut:

\section{a. Aktif Mengikuti Musyawarah dan Memberikan Usulan/Saran Perihal rencana pembangunan fisik desa}

Dalam pembangunan, tentunya diperlukan masukan-masukan atau usulanusulan dari berbagai pihak terkait dalam hal ini masyarakat desa setempat agar pembangunan dapat berbasis partisipasi masyarakat. Tahap ini dikenal dengan tahap perencanaan dengan istilah Musrembang. Musrenbang adalah forum perencanaan (program) yang dilaksanakan oleh lembaga publik yaitu pemerintah desa, bekerja sama dengan warga dan para pemangku kepentingan lainnya. Musrenbang yang bermakna akan mampu membangun kesepahaman tentang kepentingan dan kemajuan desa, dengan cara memotret potensi dan sumbersumber pembangunan yang tidak tersedia baik dari dalam maupun luar desa.

Setiap tahun pada bulan Januari, di Desa Banga Kecamatan Mawasangka diselenggarakan MUSREMBANG untuk menyusun Rencana Kerja Pembangunan Desa (RKP Desa) yang selalu diikuti dengan penyusunan dokumen Anggaran Pendapatan dan Belanja Desa (APB Desa). Kedua dokumen ini tidak dipisahkan, dan disusun berdasarkan musyawarah dan mufakat. RKP Desa dan APB Desa merupakan dokumen dan infomasi publik. Sebagaimana diketahui bahwa Pemerintah desa merupakan lembaga publik yang wajib menyampaikan informasi publik kepada warga masyarakat setempat. Keterbukaan dan tanggung jawab kepada publik menjadi prinsip penting bagi pemerintah desa.

Musrembang menjadi wadah bagi masyarakat Desa setempat untuk dapat menyampaikan beberapa usulan terkait kegiatan pembangunan desa yang akan dilakukan. Sumbangan Pemikiran Masyarakat dalam bentuk usulan/saran dalam perencaaan dan pengambilan keputusan artinya masyarakat terlibat aktif dalam memberikan ide-ide atau pemikiran dalam proses prencanaan pembangunan seperti dalam musyawarah perencanaan pembangunan desa Banga Kecamatan Mawasangka.

\section{b. Keikutsertaan dalam Pelaksanaan Pembangunan fisik desa}

Partisipasi diberi makna sebagai keterlibatan masyarakat dalam proses politik yang seluas-luasnya baik dalam proses pengambilan keputusan, pelaksanaan hingga pemantauan kebijakan yang dapat mempengaruhi kehidupan masyarakat tersebut. Tahap pelaksanaan merupakan realisasi dari berbagai program yang telah disepakati untuk dijalankan. Pada tahap ini, partisipasi masyarakat diukur dari katerlibatannya dalam memberikan bantuan baik secara materi maupun non-materi.

Partisipasi dalam bentuk non-materi identik dengan sumbangan tenaga yang masuk dalam kategori gotong royong. Maksudnya masyarakat bersama dengan pengurus pembangunan saling membantu dan meluangkan waktu untuk 
percepatan pembangunan tanpa mengharapkan upah. Sedangkan partisipasi dalam bentuk materi berupa sumbangan finansial baik yang ditetapkan besarannya perKK ataupun berdasarkan keikhlasan, juga berupa pemberian bantuan material atau bahan-bahan untuk kegiatan pembangunan yang akan dilaksanakan.

\section{c. Keikutsertaan Mengawasi, Mengevaluasi dan Memelihara Hasil Pelaksanaan Pembangunan}

Partisipasi masyarakat dalam proses pengawasan adalah masyarakat diikutsertakatan atau turut berpartisipasi untuk menjaga jalannya kegiatan pembangunan agar sesuai dengan yang telah direncanakan sebelumnya. Sedangkan evaluasi dimaksudkan untuk mengetahui pelaksanaan pembangunan berjalan sesuai dengan rencana yang telah ditetapkan atau tidak. Evaluasi merupakan salah satu aspek yang penting dalam pelaksanaan rencana sebagai bagian dari proses perencanaan yang menyeluruh. Selanjutnya pemeliharaan merupakan bagian dari tanggung jawab bersama untuk menjaga hasil dari pembangunan yang telah dilakukan agar manfaatnya dapat dirasakan secara menyeluruh dan berkelanjutan.

\section{Faktor-Faktor yang Mempengaruhi Partisipasi Masyarakat dalam Pembangunan Fisik di Desa Banga Kecamatan Mawasangka}

Masyarakat berpartsipasi dalam proses pembangunan karena adanya kesadaran bahwa pembangunan yang diprogramkan/dilaksanakan merupakan kebutuhan. Agar masyarakat dapat berpartisipasi aktif dalam proses pembangunan, maka ada tiga faktor yang secara pribadi harus dipunyai oleh setiap anggota masyarakat yaitu; kemauan, kemampuan, dan kesempatan. Untuk menumbuhkan partisipasi itu, maka prasyarat dan unsur-unsur pendukungnya haruslah benarbenar diperhatikan, terutama kemauan, kemampuan dan kesempatan masyarakat dalam berpartisipasi. Apabila ketiga faktor ini telah dipunyai oleh setiap anggota masyarakat, partisipasi yang kita harapkan akan nampak. Apabila program pelaksanaan pembangunan dapat tercapai, disitulah masyarakat akan menikmati kesejahteraan sesuai dengan amanah UUD 1945.

Ada beberapa faktor yang dapat mempengaruhi partisipasi masyarakat dalam suatu program, sifat faktor-faktor tersebut dapat mendukung suatu keberhasilan pembangunan namun ada juga yang sifatnya dapat menghambat keberhasilan pembangunan. Hal yang sama juga terjadi di desa Banga Kecamatan Mawasangka Kabupaten Buton Tengah. Berpartisipasinya masyarakat desa Banga juga ditentukan oleh 5 faktor diantaranya: (1) pengetahuan dan keterampilan; (2) pekerjaan masyarakat; (3) tingkat pendidikan; (4) jenis kelamin; (5) kepercayaan terhadap budaya tertentu. Adapun penjelasan lebih lanjut dari setiap indikator dapat dirincikan sebagai berikut:

\section{a. Pengetahuan dan Keterampilan}

Pengetahuan dan keahlian merupakan dua konsep yang berbeda namun memiliki keterkaitan satu sama lain. Pengetahuan dalam hal ini adalah suatu kondisi dimana masyarakat mampu memahami arti dari pembangunan yang dilakukan yakni untuk kesejahteraraan masyarakat setempat. Sedangkan keahlian merupakan bentuk yang lebih mendalam dari pengetahuan dimana pengetahuan yang dimiliki dapat digunakan untuk melakukan atau membantu proses pembangunan dalam setiap tahapannya atau lebih dikenal dengan istilah skill. 


\section{b. Tingkat Pendidikan}

Dikatakan sebagai salah satu syarat untuk berpartisipasi. Pendidikan dianggap dapat mempengaruhi sikap hidup seseorang terhadap lingkungannya, suatu sikap yang diperlukan bagi peningkatan kesejahteraan seluruh masyarakat. Tingkatan pendidikan akan mempengaruhi pola pikir seseorang yang semakin luas dan kompleks. Sebagaimana dijelaskan oleh M Noor Syam bahwa Pendidikan adalah aktivitas dan usaha manusia untuk meningkatkan kepribadiannya dengan jalan menimba potensi-potensi pribadinya yaitu rohani (pikir, karsa, cipta dan budi nurani) dan Jasmani (panca indera serta keterampilan-keterampilan) (Tim Dosen FIP-IKIP Malang, 1980:7). Tingkat pendidikan juga menjadi salah satu faktor yang mempengaruhi partisipasi masyarakat desa Banga dalam pembangunan fisik Desa.

\section{c. Pekerjaan dan Penghasilan}

Pekerjaan dan penghasilan tidak dapat dipisahkan satu sama lain karena pekerjaan seseorang akan menentukan berapa penghasilan yang akan diperolehnya. Pekerjaan dan penghasilan yang baik dan mencukupi kebutuhan sehari-hari dapat mendorong seseorang untuk berpartisipasi dalam kegiatan-kegiatan masyarakat. Artinya bahwa untuk berpartisipasi dalam suatu kegiatan, harus didukung oleh suasana perekonomian yang mapan. Pekerjaan dan penghasilan menjadi salah satu faktor yang mempengaruhi partisipasi masyarakat desa Banga dalam pembangunan. Sebagaimana diketahui bahwa masyarakat desa Banga melakoni pekerjaan yang beragam dengan tingkat penghasilan yang beragam pula.

\section{d. Jenis Kelamin}

Nilai yang cukup lama bertahan dan berkembang dalam kultur berbagai bangsa mengatakan bahwa pada dasarnya tempat perempuan adalah "di dapur" yang berarti bahwa dalam banyak masyarakat peranan perempuan yang terutama adalah mengurus rumah tangga, akan tetapi semakin lama nilai peran perempuan tersebut perlahan bergeser dengan adanya gerakan emansipasi wanita dan pendidikan perempuan yang semakin membaik dan maju. Hal tersebut terjadi pula dalam partisipasi masyarakat di Desa Banga.

Jenis kelamin yakni laki-laki dan perempuan juga menjadi salah satu faktor seharusnya mempengaruhi partisipasi masyarakat desa dalam pembangunan. s.u tersebut justru tidak tampak di desa Banga Kecamatan Mawasangka. Kendatipun peranan perempuan tidak dapat disamakan presentasenya dengan laki-laki, namun keberadaan perempuan dalam partisipasi pembangunan di desa Banga cukup signifikan.

\section{PENUTUP}

\section{Kesimpulan}

Berdasarkan uraian hasil penelitian dan pembahasan maka dapat disimpulkan beberapa hal sebagai berikut:

1. Partisipasi masyarakat dalam pembangunan fisik desa diklasifikasikan dalam tiga bentuk, yakni:

a. Keikutsertaan dalam musyawarah dan memberikan usulan/saran perihal program pembangunan yang akan dijalankan untuk disetujui bersama. Bentuk ini merupakan bagian dari tahap perencanaan pembangunan. Secara konkret berwujud: kehadiran masyarakat dalam setiap pertemuan, memberikan beberapa usulan/masuka-masuk dalam pertemuan, hingga 
terlibat dalam pertemuan nonformal yang membahas program pembangunan yang akan dilaksanakan.

b. Keikutsertaan dalam pelaksanaan/realisasi program pembangunan. secara konkret berwujud sumbangan berupa tenaga, pikiran, dana, alat-alat/bahanbahan kerja.

c. Keikutsertaan mengawasi, mengevaluasi dan memelihara hasil pelaksanaan pembangunan. Pengawasan dan evaluasi secara sederhana berfungsi untuk mengetahui sejauh mana suatu pembangunan berjalan sesuai dengan ketentuan yang telah ditetapkan. sedangkan evaluasi, dari evaluasi akan diketahui penyimpangan-penyimpangan atau permasalahan yang terjadi saat pelaksanaan kegiatan pembangunan desa sehingga dapat diambil langkah-langkah kebijaksanaan korektif agar pelaksanaan kegiatan sesuai dengan rencana yang telah ditetapkan.

2. Terdapat empat faktor yang mempengaruhi partisipasi masyarakat dalam pembangunan fisik desa yakni:

a. Pengetahuan dan keterampilan yang mengambil bagian pada semua tahapan pembangunan dari perencanaan/penggagasan, pelaksanaan/ realisasi, hingga pengawasan, evaluasi dan pemeliharaan;

b. Tingkat pendidikan yang mengambil bagian juga pada pada semua tahapan pembangunan dari perencanaan/penggagasan, pelaksanaan/ realisasi, hingga pengawasan, evaluasi dan pemeliharaan. Tetapi terdapat partisipasi dominan yang diklasifikasi pada dua tingkatan pendidikan yakni maksimal tamat SMP dan Minimal tamat SMA;

c. Pekerjaan dan penghasilan merupakan dua hal yang tidak dapat dipisahkan karena besarnya penghasilan seseorang bergantung pada jenis pekerjaan yang ditekuninya. Pekerjaan dan penghasilan memberikan pengaruh besar pada partisipasi dalam bentuk perencanaan/ penggagasan dan realisasi program pembangunan.

d. Kebudayaan yang memberikan pengaruh yang cukup besar dan positif untuk pembangunan desa yakni melalui adanya budaya gotong royong yang menjadikan percepatan pembangunan dapat terwujud mengingat adanya kebiasaan dalam pekerjaan umum yang dilandasi kewajiban dan rasa tanggung jawab bersama antarsesama masyarakat desa.

\section{Saran}

Adapun saran yang bisa penulis berikan adalah sebagai berikut:

1. Bagi pihak pemerintah desa diharapkan untuk selalu memberikan kesempatan yang sama kepada setiap anggota masyarakat dalam berpartisipasi. Upaya yang telah dilakukan sebelumnya dalam rangka meningkatkan partisipasi masyarakat dalam segala bentuk tetap perlu ditingkatkan untuk kemajuan desa secara maksimal. Mengingat terdapat banyak faktor yang mempengaruhi partisipasi masyarakat yang dapat berdampak negatif maka pihak pemerintah desa harus selalu mengupayakan perbaikan dan peningkatan pelayanan masyarakat, memfasilitasi masyarakat dalam pelaksanaan pembangunan, mengajak masyarakat untuk tidak berhenti terlibat aktif dalam partisipasi, dan menggemakan budaya gotong royong dalam setiap kegiatan kemasyarakatan khususnya pada pembangunan desa. 
2. Bagi seluruh masyarakat desa diharapkan agar selalu menunjukkan dukungannya pada pemerintah desa dengan berpartisipasi aktif dalam berbagai bentuk pembangunan desa. Harus selalu menjaga dan mempertahankan serta melestarikan gotong royong sebagai suatu budaya yang dapat bermanfaat pula bagi percepatan pembangunan desa.

\section{DAFTAR PUSTAKA}

Adisasmita, Rahardjo. 2006. Membangun desa partisipatif. Yogyakarta: Graha Ilmu

Chandra, Eka dkk. 2003. Membangun Forum Warga: Implementasi Partisipasi dan Penguatan Mayarakat Sipil. Bandung: Yayasan Akatiga

Dusseldorp, D.B.W.N. 1981. Participation in Planned Development Influced by Goverments of Developing Local in Rural Areas. Wageningen: Wageningen University (terjemahan)

Dwiningrum, Siti Irene Astuti. 2015. Desentralisasi dan Partisipasi Masyarakat dalam Pendidikan. Yogyakarta: Pustaka Pelajar

Ndraha, Taliziduhu. 2002. Pembangunan Masyarakat. Jakarta: Rineka Cipta

Fatimah, Siti. 2012. Analisis Faktor-Faktor yang Mempengaruhi Partisipasi Masyarakat dalam Pembuatan E-KTP di Desa Taratak Buluh Kecamatan Siak Hulu Kabupaten Kampar (Skripsi). Pekanbaru: UIN Sultan Syarif Kasim Riau

Tjokroamidjojo, Bintoro. 2004. Perencanaan Pembangunan. Jakarta: Gunung Agung

Sugiyono, 2014. Memahami Penelitian Kualitatif. Bandung: ALFABETA

Sumaryadi, I Nyoman. 2010. Partisipasi Masyarakat. Jakarta: Rineka Cipta

Soekanto, Soerjono. 1999. Sosiologi Hukum suatu Pengantar. Jakarta: PT Raja Grafindo Persada

Slamet. 1994. Pembangunan Masyarakat Berwawasan Partisipasi. Sebelas Maret University Press : Surakarta.

Syani, Abdul. 1995. Sosiologi dan Perubahan Masyarakat. Bandar Lampung: Pustaka Jaya. Unila

Sedermayanti dan Hidayat. 2011. Metodologi Penelitian. Mandala Maju : Bandung.

Septyasa, Laksana Nuring. 2013. Bentuk-Bentuk Partisipasi Masyarakat Desa dalam Program Desa Siaga di Desa Bandung Kecamatan Playen Kabupaten Gunung Kidul Provinsi Daerah Istimewa Yogyakarta. Jurnal Kebijakan dan Manajemen Publik: Vol.1 No.1. Diakses pada 20 Februari 2018

Tjiptoherijanto, Prijono. 1993. Migrasi, Urbanisasi dan Pasar Kerja di Indonesia. Jakarta: Penerbit Universitas Indonesia Press

Tilaar. H.A.R 2009. Kekuasaan Pendidikan: Kajian Manajemen Pendidikan Nasional dalam Pusaran Kekuasaan. Jakarta: Rineka Cipta

Kansil, C.S.T. 2011. Sistem Pemerintahan Indonesia (Edisi Revisi). Jakarta: Bumi Aksara

Kurniawan, Fauzi. 2016. Beberapa Teori tentang Pembangunan: http://beberapateori tentang-pembangunan-dan.html post 29-03-2016, diakses pada 20 Maret 2019

Undang-undang Nomor 43 Tahun 2014 tentang Desa 